Cinémas

Revue d'études cinématographiques

Journal of Film Studies

\title{
Lyda Borelli's Satanic Rhapsody: The Cinema and the Occult
}

\section{Angela Dalle Vacche}

Volume 16, numéro 1, automne 2005

Femmes et cinéma muet : nouvelles problématiques, nouvelles méthodologies

URI : https://id.erudit.org/iderudit/013052ar

DOI : https://doi.org/10.7202/013052ar

Aller au sommaire du numéro

Éditeur(s)

Cinémas

ISSN

1181-6945 (imprimé)

1705-6500 (numérique)

Découvrir la revue

Citer cet article

Vacche, A. D. (2005). Lyda Borelli's Satanic Rhapsody: The Cinema and the Occult. Cinémas, 16(1), 91-115. https://doi.org/10.7202/013052ar
Résumé de l'article

Analysant Rapsodie satanique (Rapsodia Satanica, 1915), film de Nino Oxilia donnant la vedette à Lyda Borelli, l'auteure du présent article met en lumière l'effet du bergsonisme sur la perception qu'on avait du cinéma juste avant et pendant la Première Guerre mondiale. Parmi les nombreuses sources d'inspiration d'Oxilia, elle souligne plus particulièrement l'influence de la tradition des films de divas du cinéma italien naissant, du dynamisme plastique du peintre futuriste Umberto Boccioni, des chorégraphies et performances de Loïe Fuller, ainsi que celle de la figure émergeante de la Femme Nouvelle. 


\title{
Lyda Borelli's Satanic Rhapsody: The Cinema and the Occult
}

\section{Angela Dalle Vacche}

\begin{abstract}
Discussing Nino Oxilia's film Satanic Rhapsody (Rapsodia Satanica, 1915) starring Lyda Borelli, the author examines the influence of Bergsonism on the perception of cinema right before and during World War I. In particular, she points out the intersection between the film and, among other references, the tradition of the early Italian diva film, the plastic dynamism of Futurist painter Umberto Boccioni, the dance/performance art of Loïe Fuller, and the emerging figure of the New Woman.
\end{abstract}

\section{RÉSUMÉ}

Analysant Rapsodie satanique (Rapsodia Satanica, 1915), film de Nino Oxilia donnant la vedette à Lyda Borelli, l'auteure du présent article met en lumière l'effet du bergsonisme sur la perception qu'on avait du cinéma juste avant et pendant la Première Guerre mondiale. Parmi les nombreuses sources d'inspiration d'Oxilia, elle souligne plus particulièrement l'influence de la tradition des films de divas du cinéma italien naissant, du dynamisme plastique du peintre futuriste Umberto Boccioni, des chorégraphies et performances de Loïe Fuller, ainsi que celle de la figure émergeante de la Femme Nouvelle. 
Nino Oxilia's Rapsodia Satanica (1915), or Satanic Rhapsody, with Lyda Borelli, is an important silent film to examine because of the ways in which it weaves together so many cultural threads of its period. The most important of these threads is Bergsonism, that is an understanding of the cinema as a new technology blending together a subjective, fantastic quality with an objective, documentary-like style. Originally, in Creative Evolution, Henri Bergson (1998) associated the cinema of his day with science and the illusions of intelligence. This is the case because the motion studies that he knew by Etienne-Jules Marey were so analytical and compartmentalizing that they did not, during the course of observation, take into account the subjective powers of memory, intuition and imagination. Yet, through Giovanni Papini, an Italian disciple of Bergson, this opposition between cinema and subjectivity became much less rigid. ${ }^{1}$ By referring to the print of Rapsodia Satanica restored by the Cineteca di Bologna, in this essay I will argue that Nino Oxilia probably knew Bergson's work through his friend, the painter and film producer Pier Antonio Gariazzo. I will also contend that, just like Papini, Oxilia feels that the cinema is a combination of fantastic and documentary-like moments, so that his style alternates betweeen outdoor scenes with natural lighting and indoor episodes with a Caravaggesque chiaroscuro. This mix of styles is all about the transition from old to new, the passage from the stuffy interiors of a castle to freer gardens with butterflies, winds, clouds, and trees. In the case of Rapsodia, the theme of an identity in search of change applies, of course, to the film-diva Lyda Borelli.

Rapsodia Satanica is a diva-film, that is a work built around a female star whose marketing prestige overshadowed even the reputation of the director, Nino Oxilia. Although widely used in contemporary English, the word diva in 1915 Italy meant something different from what it means today. Most people associate the term with a strong, beautiful and dangerous woman, derived from the nineteenth-century femme fatale of painting and literature. Such a definition is relevant to the film-diva of early Italian cinema, but only in a limited way, since the female stars of that period were characterized by a suffering and maternal 
aura (mater dolorosa) which the American femme fatales never adopted. Furthermore, in early Italian cinema a diva-film meant a melodrama with Orientalist décor dealing with women's issues such as aging, abandonment, divorce, adultery, pregnancy, employment and so forth.

In the case of Rapsodia Satanica, Borelli's character becomes the conceptual centerpiece of the whole film. To be sure, she was a famous star of the stage, until 1913 when she agreed to work in Everlasting Love with director Mario Caserini. Borelli's success with her first film experience was enormous: a new film genre was born along with a new kind of female stardom, so that the young actress' manners became a fashionable mode of behaviour for millions of young Italian women. In the wake of such an explosion of celebrity for Borelli, when the young Nino Oxilia was chosen by Cines, a Roman production house to direct Rapsodia Satanica, it was a great opportunity for his artistic career. As a film concerned with romance, aging, physical beauty, and personal happiness for a powerful woman who lives alone, Rapsodia Satanica fits within the genre of the diva-film, but Oxilia used every element at his disposal to raise the stakes of the genre itself from within and to move the whole project in a more philosophical and experimental direction.

More specifically, there are at least two reasons why Oxilia's Rapsodia Satanica stands out in comparision to similar films from the same period. Firstly, Rapsodia Satanica exhibits a fascination with the late nineteenth-century obsession with occult forces intertwined with an Orientalist agenda. Just a few years before the shooting of Oxilia's film, the Italians' taste for the exotic and the esoteric had been kindled by the arrival of Diaghilev's Ballets Russes in Rome. Secondly, Rapsodia Satanica is concerned with the theme of temporality, or the so-called "fourth dimension," a key topic in Italian circles studying the borderline between scientific and paranormal phenomena. The film's preoccupation with time demonstrates the wide-spread influence of Henri Bergson's philosophy of duration. In contrast to a traditional, linear, and teleological understanding of history, Bergson's duration or the resilience of an imaginative impulseélan vital - was a whole new way of thinking about subjectivity 
and creativity which shaped the ideas of many Italian intellectuals in Oxilia's time. To better understand how so many different strands play themselves out in Rapsodia, I will devote a series of sections to a close-up examination of the artistic and intellectual network of forces that have shaped this little-known but unusual, "experimental" melodrama.

\section{Nino Oxilia}

Born in Turin, Nino Oxilia (1889-1917) was involved in poetry, songwriting, and theatre, before turning to film. As a young man, he was a bohemian; it might be going too far to call Oxilia a protofeminist, but he was a friend of poet Guido Gozzano and his companion, the writer Amalia Guglielminetti. This high-profile couple was engaged in debates about social reform and the emancipation of women (though Gozzano's inclinations were more melancholic and conservative than Oxilia's). Turin at the time was teeming with Socialists, suffragettes, and ladies active in philanthropy and salons; due to its proximity to France, Turin was also a center of filmmaking for the rest of Italy. Vittorio Calcina, the first representative of the Lumiere Brothers in Italy, was based there. Between the eighteen-eighties and eighteen-nineties, Turin had become, through Edmondo De Amicis' heartbreaking feuilletons about immigration, poverty, and education, the city of patriotic piety, socialism, and the Italian Risorgimento. Antonio Gramsci, another native of Turin, split from the Socialists in 1919 to found the brand new Communist Party in the wake of the Bolshevik Revolution. Turin was the city of criminal anthropology. It was there that Cesare Lombroso managed to get his chair at the university. One component of the emerging industral triangle with Milan and Genoa, Turin was different from other Italian cities due to the scientific, secular tradition fostered by the French Enlightment across the Alps. ${ }^{2}$

While the Scapigliatura was an artistic youth movement inspired by the French boheme, all sorts of mystical and religious cults, as well as esoteric and exotic fashions, were also flourishing there as a reaction against the mathematical certitude at the service of industry and the Turinese liberal-conserva- 
tive oligarchy. Oxilia grew up in this Turinese climate of technological and artistic experimentation where irrational beliefs went hand in hand with scientific testing. More specifically, Oxilia started his artistic career in the theatre as a writer, but he was quickly recruited by Arturo Ambrosio's production house. By 1912, Oxilia became very close to Pier Antonio Gariazzo, a painter, filmmaker, and producer; he was also the founder of Savoia Film, a company that specialized in contemporary dramas. Always eager to be informed about the latest trend, Gariazzo dabbled in philosophy, loved adventure, and traveled extensively (his experiences in Indonesia inspired several paintings). Turin was also the home of Adriano Tilgher, a minor philosopher, who became a disciple of Henri Bergson and wrote the book Art, Knowledge and Reality (1911) (Arte, conoscenza e realtà). In this stimulating environment, the young Oxilia met his future fiancée, Maria Jacobini, a young actress who looked like Mary Pickford and was also the niece of a Vatican-based cardinal. Jacobini left her parents' house in Rome amid great scandal, to become a diva and devote herself entirely to the cinema. ${ }^{3}$ Oxilia fell in love and became her Pygmalion. In 1913, after many projects in the Turinese film environment, Oxilia signed a contract with Cines, a prestigious production house based in Rome, which asked him to work with Francesca Bertini for Sangue Blue through its subsidiary company, Celio. In 1915 Oxilia wrote Il Fior di Male, a film beautifully interpreted by Lyda Borelli for the director Carmine Gallone. In 1916, when the brief season of divas was nearly over, and blood and death were flooding the Italian screens, Oxilia shot a couple of war newsreels set in the Balkans. His images were so gruesome that the censorship board intervened. In 1917 Oxilia died on the front line, blown to pieces by a bomb during the battle of Monte Tomba. He was one among many artists and intellectuals of that confused yet remarkable generation who died in the Great War; the painter Umberto Boccioni and the architect Antonio Sant'Elia met the same fate. The diva-film, thus, found itself lacking intellectual mentors to improve the genre and open it up to experimentation with new ideas about women and visual technologies. 
Overall Oxilia's style as a director was quite fluid, and it is, therefore, difficult to determine exactly what his specific contributions were. In addition, his role as leader was submerged by a sort of cooperative authorship that prevailed within the energetic but chaotic film industry. So open to experimentation was Oxilia that, during the shooting of Ananke (Fate, 1915) with Leda Gys, Maria Jacobini, and Maria's sister, Diomira Jacobini, he let the three divas handle most of the creative decisions and limited himself to the role of set designer. What is sure, however, is that he directed not only Bertini in Sangue Blue and Borelli in Rapsodia Satanica, but also Pina Menichelli in Il Papà (Daddy, 1915) and in Il Sottomarino 27 (Submarine 27, 1915), two films that unfortunately have been lost. Because he worked with the most important divas of his period, it is likely that Oxilia had a reputation inside the industry which was competitive with that of Mario Caserini, Carmine Gallone, and Giovanni Pastrone. Between 1912 and 1917, the year of his death, Oxilia was involved in at least twenty-four films-all of them made one after another and at breackneck speed.

\section{Rapsodia Satanica}

The point here is that enough positive energy surrounded the young filmmaker to sustain him in a constructive way during the production of Rapsodia Satanica. And this climate of openness to new ideas and cosmopolitan trends may indicate why Oxilia celebrates women's sense of independence with an explicit citation of Loïe Fuller's dancing performed by Lyda Borelli in Rapsodia Satanica. By 1915 Loïe Fuller, an American dancer who triumphed in Paris, was a well-established icon of women's emancipation and the artistic integration of technology, science and imagination. Most significantly, her dances, performed in complete darkness with phosphorescent veils and colored electric lights mounted on wands, were comparable to a proto-cinematic show; even the Italian Futurists praised Fuller's work unreservedly.

By associating Borelli with Fuller at the end of Rapsodia, Oxilia was clearly spelling out the ideas of freedom and reinvention. Such a feminist use of a famous diva was no small state- 
ment, and, as such, it put him in a potentially compromising position. But referencing Fuller was not the only risk Oxilia was ready to take. In Rapsodia, Borelli, before turning into a sort of butterfly of the future, impersonates a cruel Salome. This reference was mandatory because Borelli conquered Italian audiences by playing Salome on stage in 1902 . Yet it was also a bit risky to associate film and femininity with an Orientalist myth. On the other hand, cinema's bad reputation as the conduit of evil from the East to the West, did nothing to slow down the Orientalist vogue in early Italian film culture.

Through Borelli dressed as Salome, Oxilia's Rapsodia explores the transformation of the cruel femme fatale into the New Woman of modernity, while it also interrogates the cinema about its affinities with the outdoors or the natural world in contrast to the alliance between theatre and architecture, or the indoors and furniture. Oxilia's Rapsodia was shot and finished in 1914, but not distributed until 1917 due to unspecified difficulties. It seems that there was some rivalry with Mario Caserini (1874-1920), who was based in Rome and linked to Cines just as Oxilia was. Perhaps Caserini himself was instrumental in holding the film up. One of the producers of the film at Cines was the Baron Alberto Fassini, also known as Alfa, who had strong ties with the Bank of Rome and financed the project.

Fassini brought in the composer Pietro Mascagni and asked him to write the music. After watching the film over and over again without intertitles, Mascagni felt strongly that the music should rule over the image. He declared that he envisioned a score at least fifty-five minutes long. As a result, Oxilia agreed to redo the ending so as to match the length of Mascagni's score. Some argue that the reason why Rapsodia Satanica stood on the shelf until 1917 was Mascagni's endless revising. He was unwilling to declare he had completed the final version of the score until 1917, even though most of the music was written by $1915 .^{4}$

Rapsodia's plot is easy to summarize. An old woman, Alba D'Oltrevita, whose names means Dawn-Beyond-Life (Lyda Borelli), tired of wasting away and fearing death, makes a deal with the devil: she will be young and beautiful forever if she 
gives up romance. The idea of giving up romance and achieving eternal youth involves breaking the statuette of a little Cupid standing near an hour glass. Yet Alba's statuette does not break. Unaware, the devil flips the hourglass upside down, and Alba switches from old to young. The owner of the Castle of Illusion (an obvious architectural allegory of the movie theatre), Alba embodies not only the life-preserving power of the filmic image, but the dream of reversing the death-bound flow of time.

In keeping with a self-reflexive reading of Oxilia's film, Alba's character can be linked to two separate images of time- two complementary views of the cinema involving two other famous female stars of silent film culture. The first image involves Ida Rubinstein, the famous Russian dancer from the Ballets Russes. Her first appearance on a Parisian stage in 1909 mesmerized the audience, especially when her body appeared to be slowly emerging out of an unraveling, cocoon-like strip of cloth. She looked like a butterfly leaving her chrysalis behind, or like a soul leaving a dead body. An ancient symbol for the immortal soul, the butterfly is a major icon of Art Nouveau. The second image is a photograph of Theda Bara staring at an Egyptian mummy stored in a glass case. The first example is about the time of projection, whereas the second is about the cinema holding forever still a moment that is as unique and as precious as the human body preserved through mummification. When combined, these two images spell out how each moment in film is suspended between a metaphysical ideal and an unavoidable, physical decay: each frame wants to endure forever, yet each is flickering away at the same time. Rapsodia Satanica is an allegorical meditation on the inner and outer temporalities of the filmic image - that is, the filmic image is as transient as Alba's youth but, thanks to its photographic ontology, the image in film is also as long-lasting as an Egyptian mummy.

Rapsodia's plot unfolds through episodes of jealousy and selfdestruction between Alba and two brothers who are both in love with her. Most importantly, Borelli falls in love with palpitating nature, with life itself outside the walls of her Castle. Alba's home is surrounded by a series of gardens, ranging from highly designed and cultivated plots to the forgotten corners where 
plants grow wild. While she is walking alone in a secluded corner of her huge park, she surprises a yellow butterfly resting on a flower. The distance between her and the object of her gaze is hardly established, and it is for this reason that the cut from a close-up of her face to a close-up of the butterfly cannot complement each other within the system of the point-of-view shot. In the passage from one shot to the next, today's spectator can sense that the spatial proportions are off: the size of objects in the first shot looks awkward in relation to the size of those contained in the second.

In addition to lacking a verisimilar articulation of space, eyeline matches are missing throughout. Alba's gaze upon a group of musicians below her window is incomplete. The reactionshot necessary to legitimize the inference of a point-of-view shot is not there. Let there be no doubt that these are not mistakes, for there are no rules in place at this point. This is why these particular examples are also responsible for the flavor and texture of the film, for all its rough edges and moments of surprise.

Despite the limitations typical of early cinema, the steady alternation between indoor and outdoor space suggests that Oxilia might have been wondering about film's special kinship with nature. The director's energy seems to be torn between cramped art-historical allusions within the sets and the spontaneous flow of water and the reverberations of light in the garden. Of course, most shots of the landscape include carefully arranged micro-narratives of youthful groups horseback riding or dancing into the most remote background layers of the shot.

Yet the use of natural lighting in the outdoor sequences, the feeling of fresh air, and the thin fabrics used for the costumes indicate that the cinema functions at its very best with intangible, quasi-invisible materials. On the other hand, inside the Castle of Illusion, mirrors and chiaroscuro lighting produce a dense but also alluring sense of mystery around Alba. Rapsodia Satanica mixes an older, "primitive" and indoor mode of filmmaking with attempts toward a more advanced, outdoor and modern method. Dressed as Salome during the opening costume party, Borelli slowly advances from the background to the foreground of the shot. The outline of her figure is almost lost 
in crowded compositions: rococo furniture and statuettes, arabesque-like stuccoes, walls covered with pictures of all sizes, Oriental rugs, curtains, tapestries, animal skins, gilded frames, and bibelots surround the famous diva. To be sure, it would be too easy, and also quite wrong, to dismiss Rapsodia Satanica on the basis of its Orientalist kitsch. Furniture, ornament, and drapery are much more than gratuitous decorative detail: they offer Oxilia an opportunity to emphasize plasticity, molding, and relief-namely, staging in depth-within the diva-film, which is still trying to mediate the impression of reality with a certain degree of horror vacuii, or fear of the void.

An art historical term that refers to the anxiety of filling an empty background too reminiscent of the shadowy flatness of archaic projection, horror vacuii is confirmed by how Rapsodia's accumulation of furniture arises from a fear of the void that lurks behind the empty shadows of the projection. It is quite telling that the devil literally walks into the narrative, by leaving behind the dark space of an overly gilded pictorial frame which seems both to contain and to compensate for a ghastly area of unrepresentable emptiness. On the other hand, in a film where the surfaces of mirrors reflect multiple images, such a dance of interacting projections does make up for a static camera. Halfway through the film, during the sequence about her newly found independence from the devil, the mediation of the mirror between Alba and her reflection on the glass is most effective. When she turns to face the camera, the image of her back suggests the mental, and therefore insubstantial, nature of the barrier of an invisible fourth wall. By using the mirror to turn the body into a reflection, Oxilia underlines its illusionistic and constructed nature, hence its potential for collapse. Put another way, here the mirror is no instrument of narcissistic self-deception, but rather a means of visualizing a space that leads to a kind of magical realm beyond which it might be possible to be yourself-nothing else but yourself.

Rapsodia was a film heavily backed by bankers, with extremely lavish locations, and released with an original musical score written by a major composer. It is not surprising, then, that Rapsodia Satanica included a highly selective use of color that 
was designed not so much to increase its documentary realism, but to underline its fantastic poetic moments. As we learn from Piero Antonio Gariazzo, a good friend of Nino Oxilia, at the time the film was made, the cold gray of photography appeared to be a major aesthetic limitation, so much so that mechanical reproduction was perceived as an ally of science and an enemy of fantasy. Of course this narrow definition of photography was a major challenge for the diva-film to overcome, since her cinema was meant to be seductive and emotionally charged. Gariazzo (1919, p. 100) wrote:

Quite brutally, the merciless, cold, destructive medium photography proposed to us, from time to time, a series of ugly and barren sights, and it removed us from a vague dream filled with colors and beautiful forms to take us into a monotony of grey mountains, waters, and cities, all of them resembling one another, inhabited by people just like us, small and petty little towns.

Perhaps to compensate for a wide-spread, negative view of photography, Oxilia learnt from fashion designer Mariano Fortuny-one of Borelli's favorite fashion designers-how to develop chromatic effects for Rapsodia. In his laboratory, on the Venetian island of Giudecca, by using the pochoir (stenciling) technique, Fortuny added silver and golden threads in the form of arabesques, that were either printed on or woven into the surface of precious fabrics such as velvets, silks, linens, and organza. In the case of Oxilia's film, the pochoir technique imbues the lifeless, rigid clichés of the story with an unprecedented emotional force. The stenciling of the film in color makes the images look softer. As a result, the diva's wardrobe includes clothes of yellow, blue, pink, and green; a window absorbs the light and becomes as yellow as the large butterfly, an epiphany promising Alba a future beyond the devil; during Alba's reacquisition of youth and the coming of all sorts of spring festivals, the trees are green, while Borelli's veils are pink in opposition to the devil's red cape.

In the end, color, just like life in motion, seems to belong to the outdoors and to costume, thus hinting at film's special 
power to tune into subtle changes in the body, behavior, and the natural world. In his book about the making of Diva Dolorosa, Peter Delpeut (1999, p. 24) aptly comments on the difference between the diva-films in black and white and the humanization that color brings to Tigre Reale with Pina Menichelli:

The copy from Turin had soft pink and clear blue tones. I only knew the black-and-white version. But with the color version of Tigre Reale, I understood once and for all that monochrome coloring is essential for the appreciation of silent film. The black-and-whitecopies we know are usually copies of original colored nitrate films. In the copying process it is impossible to produce a pristine black and white picture. The film material is insensitive to particular colors, it cannot read them and translate them into gray scales or tone. The color areas are incompatible with a clear black and white. Films like Tigre Reale for years were screened with grey tones. ... Everything seemed to drown into a dull blur. Copying the original color brings life back to the story and makes the film as a whole more accessible in a visual sense.

Finally, it is significant that clothes, along with Oxilia's choice of locations and sets, help the diva to direct herself. In fact, Lyda Borelli wears several of Fortuny's most famous dresses for the shooting of Rapsodia, as if she wanted to trademark the film beyond the screen into the worlds of fashion and stage art. During the planning of La Memoria dell'Altro, in her letter to the producer Alberto Fassini, she stressed over and over again the importance of clothes in her work and her admiration for Fortuny. The diva's body, the celluloid of film, the application of color-these three levels seem to converge in the project of transforming motion into a much warmer sense of breathing life, caught like a butterfly into the net of time at a stand-still, once and for all, but also with all the flavor and taste of its own epoch preserved. 


\section{Borelli and Boccioni}

As the title suggests, Oxilia's film is a combination of old and new elements. From the Greek verb rhaptein-which means both to sew and to sing-Rapsodia's plot is derivative, transformative, and transgressive. Through the well-known characters of Salome and Faust, Oxilia rehashes the themes that feminine beauty is lethal and that eternal youth is a reward worthy of any sacrifice. Much more refreshing than these worn-out ideas are the meaningful transformations of setting and mood Alba experiences when she leaves the Castle of Illusion for fresh air; when she contemplates the beautiful yellow butterfly in the garden; and, finally, when, after scattering dying flowers on the floor and playing the piano, she acknowledges the painful return of wrinkles to her face. She knows she has broken her pact with the devil and that there is no turning back. It is precisely during this memorable scene of veils and mirrors bathed in Caravaggesque chiaroscuro lighting that the viewer senses the possibility of unexpected prodigies taking over the predictable plot Oxilia has diligently followed up to this point.

Instead of ending the film with the same old grotesque Alba of the first sequence, a new, stronger, and ethereal creature emerges from the glowing twilight hour, the see-through fabric, and the reflecting surfaces of the mise en scène. This alchemy of sunset, cloth, and glass is not only a combination of flexible and mutable materials reminiscent of film's sensitivity to time-fleeting moments. It is also a protective envelope for the diva's inner and definitive change, at the moment of greatest despair: the devil has just withdrawn his promise of eternal youth. Put another way, the play of veils, the glow of candles, and the dancelike motions caught by the looking glass function as a nurturing chrysalis: they enable the butterfly-woman of the future to be born. And she comes to life against all odds. Thus, an artificial icon of the Art Nouveau period - the real butterfly Alba saw in the garden-becomes her alter ego as well as the symbol of her search for a new identity outside the rules of the Castle.

With a surprising twist of the traditional story line, Oxilia does not make Alba return to her stuffy chambers; instead, he edits the close-up of a cold, indifferent mirror, a reference to 
aging, with the low angle of an ominous black door slowly opening to a terrace overlooking a forest. Moving from the indoors to the outdoors, the filmmaker concludes this transitional sequence by juxtaposing a frontal view of Borelli, in all her toylike smallness, against a monumental Egyptianate threshold. Not only does the diva's hieroglyphic and rigid figure grow in size as she faces and walks toward the camera, but, all of a sudden, this view is replaced by one of her receding back, that is, becoming smaller. Without a doubt, Oxilias radical switch from a frontal to a rear view of Borelli underlines the crossing of a rigid boundary inside herself and in the society in which she lives.

In the end, the veils, fluttering in dance-like fashion behind her figure, around her and toward her, announce the death of Salome. The old-fashioned femme fatale is gone once and for all, to be replaced by Alba's transformation into the New Woman of modernity. By modeling herself on Loïe Fuller's famous choreography of soft fabrics and colorful electric lights, Alba becomes a sort of abstract, marvelous being with no face, no body, but radiating immense freedom and energy.

Beloved by the Italian Futurists due to her technological emphasis, Loïe Fuller mobilized the arabesque line of Art Nouveau, converting it into utopian apparitions of mystery and power. Through her long streamers of fabric and multi-colored lighting effects, the famous American dancer would represent either flames or a butterfly in flight, while the outline of abstract and endless designs would orchestrate sensations of fear, surprise, and enchantment among the audience.

Borelli's movements on the terrace are so reminiscent of Fuller's approach that the whole sequence can be said to have been co-authored by the director and the diva alike. To be sure, Oxilia had already shown great interest in Fortuny's marvels of stage lighting during the production of Ananke. There is no reason to think, therefore, that he was not eager to include an homage to Loïe Fuller in Rapsodia. Like Fortuny, the talented American had built a reputation for herself as the creator of a completely new intersection of choreography and theatre. In the mode of Fortuny and Fuller, Oxilia spent all his time, during 
the production of Ananke, dressing the walls with different kinds of cloth in order to achieve various kinds of lighting results by relying on the modulation of fabric in space.

As the co-author of the sequence inspired by Fuller, Borelli's sense of the cinema matches Oxilia's in terms of sophistication. One example of Borelli's lucid awareness of the deep ties between fashion and film comes from her preface to Mario Carli's novel Retroscena (Backstage, 1915). Tactfully aware of Carli's empty rhetorical flourishes, the actress writes about her own insights on questions of movement and fashion:

\begin{abstract}
Reading your novel has produced a strange impression in me: I have found in you a sensitivity-or better, a gamut of sensations - which I would call feminine. ... I say this not because I find your imaginative path to be either weak or frail, but simply to underline one of its most fundamental traits: the suppleness of your imagination. After all we need to get rid of the superstition which attributes to women everything which is weak and shallow. There are a lot of men who are weaker and shallower than any woman, hence it is an absolute commonplace to call us the weak sex. ... I am very interested in your fascination with clothes, with the question of women's elegance, with that fantastic and, without a doubt, complicated world which is a woman's wardrobe. I, just like you, believe that a wardrobe is a sort of poetic medium or material (Borelli 1915). ${ }^{5}$
\end{abstract}

So aware was Borelli of the power of clothing to generate autonomous forms of movement with a storytelling power of its own, that she invoked la poesia delle vesti. In other words, Borelli was describing the way in which pleats and folds, like poetry, can yield a glimpse of hidden physical energies and halfformulated thoughts. The latter are, by definition, difficult to externalize, represent, or even express not only to others, but even to oneself. Hence Borelli seems to suggest that clothes send messages to oneself nobody or nothing else would know; and that clothes narrate the histories of many different worlds.

Female narcissism is a constant theme in the visual arts of the nineteenth century, and this convention reappears in the first 
half of Rapsodia, when Alba looks at her image reflected on the surface of a pond in her garden. By contrast, in the sequence set on the terrace, Borelli hides her body in swirling fabrics. This turn toward disembodiment—and, therefore, abstraction—suggests that Oxilia's melodrama aligns itself with modernist experimentation, despite all its old-fashioned clichés. In this respect, echoes of Boccioni's "plastic" or "transcendental" dynamism can be found in Borelli's use of veils. Put another way, through Fuller's dances about the disappearance of her own body in the dark, Oxilia and Borelli elevate the standard diva-film into a Futurist-oriented form of experimental visual poetry through fabric and movement in line, through the unraveling of grammar into free analogies.

On March 30, 1907, the painter Umberto Boccioni (1971, p. $107)$ notes in his diary that he accidentally saw a young and elegant actress:

Yesterday I saw a young actress who was so elegent that
I thought that if I could study using that woman as a
model, perhaps I could find what I am really looking
for. This one or another one, as long as she carries in
herself a whole musical range of movements which I
find very typical of twentieth-century, elegant women.

In 1907 Boccioni was not yet a Futurist painter. That would happen after he met Marinetti in 1909, the year of the first Futurist Manifesto. In fact, he was still working in a Divisionist mode and, even though he does not mention Borelli's name, the link between an "actress," clothes, and motion spells out Borelli, since this was both the way she described herself and the way contemporary reviewers characterized her.

To be sure, Boccioni will address again the fact that the observation of clothes-in-motion can become a spiritual epiphany about a woman's soul when he describes his neighbor and confidant, Ines, in his diary. Boccioni's remarks about the homely Ines contain words very similar to the ones used for Borelli, and this is because he is writing more about the way he sees moderm women than the way Ines actually is. In keeping with his search for a personal and contemporary abstract style, when he used Ines as a model for The Story of a Seamstress 
(1908), the clothed surface of her figure was not only flat and two-dimensional, but it dissolved into streaks and filaments of colored light on the way to Futurist abstraction.

It was only in 1911 that Marinetti announced the Futurist Manifesto of Painting, but Boccioni was well along in his transition from Divisionism to Futurism. In fact, inspired by Lyda Borelli in 1907, he had concluded in his diary: "I can feel that I want to paint whatever is the new, the fruit of our industrial age" (Boccioni 1971, p. 107).

Influenced by Max Nordau's and Otto Weininger's writings on evolutionary theory and sexuality, Boccioni, just like the rest of the Futurists, saw women as inferior creatures. Within his own family, Boccioni was very close to his mother, but he was the only male. Thus he enjoyed being always the center of attention. By invoking a new era, therefore, the artist was not necessarily thinking about women's emancipation, but he was using the female image as a jumping board to find his own creative direction. For Boccioni "new" did not mean the "New" Woman with a whole set of rights and opportunities. It meant, instead, a novel conception of space and time in relation to the mind and the body. It was not until 1913, with the sculpture Unique Forms of Continuity in Space, that Boccioni elaborated his groundbreaking theory of "plastic dynamism." For the painter, the viewing subject and the art object should interpenetrate or intersect, simultaneously reshaping each other.

Upon closer examination, Boccioni's sculpture is "unique," as the title itself suggests, because it seems to take off within a 360-degree space. All of a sudden the stone frees itself of all gravity. Its energy level is so rotational that it seems to aspire to become a propeller, another object reminiscent of Fuller's masterful control of veils, where one wave subsides while the next one is prepared. For Boccioni, continuity in space must synthesize all three dimensions in such a way as to produce a fourth, mental one. The latter is a leap beyond the visible into the unknown. Put another way, the fourth dimension is about the projection of new configurations and forces unfolding in another space and in another time the mind can only imagine and wonder about. 
One might argue that Boccioni's famous sculpture is a mixture of old and new, because its engagement with motion does not rule out the Louvre's Nike of Samothrace as a model. The famous ancient sculpture seems to leap beyond its stasis, but it projects itself only in one direction. By contrast, Boccioni's Unique Forms of Continuity in Space achieves the paradox of a stubborn singularity within an unstable multiplicity, so that his sculpture does not simply appear to be exploring several possible trajectories of motion at the same time; instead, it looks completely different according to the angle of vision chosen by the observer. The latter, in turn, is led to think that there are many sculptures contained in one, and that each one is turning into the other within an open-ended, ever-changing simultaneity, rather than within a series based on some kind of plan or term of reference. It may seem impossible to link Oxilia's statements about filmic specificity to Boccioni's "plastic dynamism," but the director did think of the cinema as a kind of anti-theatre operating between sculpture and dance. In this sense the title of Boccioni's sculpture, Unique Forms of Continuity in Space, can be re-interpreted as a short-hand statement about cinema's specificity: it is about the temporal ontology of photography at the heart of film, while continuity in space weaves time with movement.

In a survey taken by Alberto Cavallaro and published in $L a$ Vita Cinematografica of 1913, Oxilia (quoted in Martinelli 1991, p. 83) declared:

The cinema, a corollary of the theatre? No, the cinema is an autonomous art form, with a specificity of its own. It is absolutely different from theatre. Fot it does possess ... its own deep and courageous grace. And as far as people saying that the cinema is a new art? Yes it is, in terms of its form, but not in regard to an issue of creativity. Perhaps it is a transformation of the art of posing which Euripides valued so much after all, precisely because it is the simplest, the dance of human passions - transformed for our modern mentality . . . I would call the cinema: the art of silence in the sense that it is a an art of sculptures one following the other. 


\section{Oxilia and Bergson}

Time and motion, according to Boccioni, were the most effective indications of a higher, transcendental, dynamic reality. The assumption that the temporal side is more precious than the spatial aspect distinguishes the Futurist from the Cubist agenda. The Futurist way of setting the object in motion was different from the Cubist approach. According to the Cubists, motion was an effect of showing the same thing from several sides at once. The Cubist strategy is both spatial and metonymic.

The Cubist Nude Descending a Staircase (1912) by Marcel Duchamp is about motion rearranging the elements of a single figure in line with a metonymic scattering of parts to proclaim the disintegration of the body-namely, the cohesive figure of classical painting — which tumbles down into multiple facets as if their origin had decomposed into many different, yet similar elements. Instead of producing a radical transformation of the one into the many, movement brings about the radical remapping of an old hierarchy in such a way that single parts come into contact with previously inaccessible areas of the canvas.

Still, regardless of this Cubist uprooting of corporeal features from the original body, the single figure under deconstruction retains its identity, and does not become someone or something else. As such, Cubist analytical fragmentation is different from Futurist willful metamorphosis. ${ }^{7}$

For the Futurists, motion was not the result of dismantling a figure into its elements, but rather the inner origin of a transformation which would allow multiple beings - flame, bird, flower, smoke, woman, ghost, snake, wing, feather, cloud, wave-to coexist simultaneously within the same leap of a metaphorical kind of imagination. Simultaneity, of course, has to do with time, but the Futurist approach is more visionary than analytical.

It is indeed this multiplicity of forms - one replacing another, which, in turn, becomes something else altogether-that explains the parallels between Lyda Borelli's performance at the end of Rapsodia Satanica, Loïe Fuller's dancing, and Boccioni's Unique Forms of Continuity in Space-the title of the which can 
be used as a shrewd paraphrasing of Oxilia's definition of the cinema: an art form half way between sculpture and dance. To be sure, in Rapsodia, Alba's spiritual changes manifest themsleves through the yellow butterfly, the glowingly-lit bridal veil in front of the mirror, the swirling fabrics attached to her hieratic silhouette. Each one of these visualizations, whether it stresses wings or cloth or both, is characterized by a metaphorical attempt to define femininity according to typical tropes of Art Nouveau: from the woman-butterfly to the woman-cloud.

Precisely because Loïe Fuller's method was closer to the Futurists-and later, to the Surrealists- than to the Cubist sensibility, it is fair to say that her dances appealed more to a wild imagination. In true Bergsonian fashion, Fuller's spectacles demonstrated that creativity could stem from an emphasis on imagination over logic, intuition over intellect. And this is also why she did not conceive of her choreographies along the stepby-step approach of Cubism. The latter required a rearrangement of parts with the end result of dispersing the centrality of the self into several, disjointed, and spatially competing points of view. The Cubist scattering of corporeal parts involves the possibility of assembly and reassembly according to either a previous model or a new one. Yet, whether it points towards the past or the future, Cubist logic is mechanical, or closer to the engineering ethos of another avant-garde movement, Russian Constructivism. A certain degree of organicism remained at the heart of Fuller's dances, in the sense that the sweeping motion trails of her colored lights and fluttering veils are comparable to Bergson's implicit use of a kinetic metaphor for his concept of élan vital or vitalistic impulse, as that which turns human experience in a constant ever-shifting milieu of change.

From Fuller to Boccioni, to Borelli and Oxilia, this associational and analogical approach resonated with many tendencies of the period: the obscure yet crucial links between feminism and occult practices; the esoteric taste found in the Ballets Russes; as well as the Romantic ancestry of the diva-film, the genre of love and death, growth and decay. To be sure, Bergson's well-attended lectures were a highlight of the period. ${ }^{8}$ In his essay "Enrico Bergson," from a collection about the history of 
philosophy, Twenty-Four Brains (Twenty-Four Cervelli), Papini (1922, pp. 317-318) underlines that the philosopher's lectures were crowded with women:

Since 1910 Henri Bergson . . . is the most famous philosopher on the surface of the earth admired by the women cerebrali who fill up the College de France. Some puritanical individual has decided that Bergson's philosophy is worth nothing at all, and that it will pass after a brief celebrity, just like the chairs from the Viennese Secession and the dancers of the Ballets Russes, and this rushed conclusion stems from having seen the usual "blue-stocking ladies" agitate themselves after the author of Matter and Memory along with the usual dandies who want to be in touch with the latest fads, but they are really the last to know anything.

Boccioni presumably would not have been mesmerized by Borelli as a film-diva, because he is known to have used the word "filmmaker" to insult Anton Giulio Bragaglia, a Futurist experimental photographer. Significantly, in 1907, Lyda Borelli was still a star of the theatre, and she continued her theatrical activity even after moving into film in 1913. Most likely she considered the new medium to be much less prestigious than the theatre, and as such she would work on both stages by keeping a dressing room between the shooting set and the theatrical area. Thus the link between Borelli and Boccioni is complex, because the motionless art of painting comes up against movement on screen, while movement in real life is how the actress seduces the painter into new ideas about his art.

In tracing the connection between Boccioni and Borelli, we find an intricate web of both negative and positive attitudes towards the old and the new, between cinema and theatre, and cinema and painting. In contrast to this, one might characterise the ties between the American dancer Loïe Fuller and Henri Bergson's philosophical sense of life as a form of constant change open to both the past and future, namely duration. This dynamic has been eloquently discussed by Tom Gunning (2003, pp. 86-87):

One would be hard put to conceive of a better image of Bergson's contrasting, new, dynamic understanding 
of duration than the dances of Loïe Fuller. "In reality," Bergson claimed, "the body is changing form at every moment; or rather there is no form, since form is immobile and the reality is movement. What is real is the change of form: form is ony a snapshot view of a transition." If form is a snapshot of a transition, Fuller's dance, as the art of motion, seemed to offer forms dissolved by the cinema.

Gunning's research on Fuller and Bergson expands our understanding of how Bergson's thought can be applied to the early cinema before World War I in ways that go beyond the philosopher's views on Marey's motion studies at the end of the nineteenth century. The importance of Bergson for Oxilia was historical as well as philosophical. This is to say that if Bergson was on Oxilia's intellectual horizon in Turin, his key ideas reached the filmmaker mixed with many other fads, patterns, and obsessions from that period. For instance, the contamination of Bergson's ideas with Wagnerian and Nietzschean strains will become more explicit a few years after Oxilia's death, in Ricciotto Canudo's Helen, Faust and Us. Written in 1920 but published only in 1927, the title of this essay is a plain and simple summary of Rapsodia's plot: Helen of Troy stands for beauty, Faust stands for aging, and, the pronoun "us" brings in the dimension of temporality, since the audience of cinema changes each time. But besides the Paris-based and therefore geographically-distant Canudo, Oxilia's friend, Gariazzo, was one of the many popularizers of Bergson through his book Teatro muto. He composed this paragraph in 1918 while serving as a soldier on the front line:

We want to dream for our future a theatre made of shiverings instead of analysis; we do not want a theatre made of narratives, with long Byzantine convolutions, but we want life itself transformed by art through a prismatic refraction: disassembled into its most beautiful colors: one beam after another. We shall remove from the Book of Time, grey, monotone pages, in such a way to lengthen and intensify time itself. We shall fill each single instant of our universe, by opening up to every possible vibration. Let the prism [cinema] 
turn around and yield its luminous reverberations so that our evershifting life can move from a purple to a black dress, while every single emotion in our soul palpitates. This is my wish!! (Gariazzo 1919, p. 331)

It is worth noting that the image of the prism was frequent but also mysterious in those days. Gariazzo relies on this optical analogy probably to refer to the cinema, while Lyda Borelli in Amleto Palermi's Carnevalesca uses the prism to introduce the sections into which the narrative is divided. My understanding is that the prism as a new kind of possible cinema signified distortion and transformation in contrast to a simple pair of glasses to see better or in antithesis to the reflecting surface of a passive mirror. There seems to be a confused yearning for an avantgarde aesthetic in film that never came about, but which Gariazzo was trying to articulate by bringing together Gozzano's and D'Annunzio's search for marvelous abstractions, Boccioni's longing for an artistic and willful kind of transcendence through plastic dynamism, and Bergson's spiritualism heightened with a Futurist cult of vibrations and chronomatism.

To conclude, although Oxilia's Rapsodia Satanica associated Borelli with Fuller and the New Woman of the future, the ending of the film, in which the devil prevails over Alba, produces a precarious compromise between the past and the present, between the interiors of the castle and the open spaces of tomorrow. In fact, Alba's dance of veils on the terrace is not enough to protect her from Satan's punishment. The last few images of Rapsodia show Borelli lost in a thick forest until she ends up under the devil's cape with an attitude of resigned subordination.

This punitive ending is typical for the diva-film, but Oxilia, being young and ambitious, may have hidden another level of interpretation in his standardized conclusion. One may speculate that the devil does not only embody the Catholic Church's idea of sin, but also stands for occult forces comparable to the cinema itself as a medium suspended between magic and technology. Only Lucifer has the power to reverse time's forward moving trajectory. This is why Oxilia's Rapsodia can only be Satanica, because, even though he aligns women's emancipation 
with cinema's creativity, in the end he seems to side more with his medium (cinema) and the occult (Satan) rather than with the diva's impossible search for romantic love and eternal beauty. Such a conclusion is not surprising. Here Oxilia is the Turinese bohemian who chooses the devil, the first maker of anti-conformist choices. Such a stance does not only entail a rejection of scientific Positivism in favor of Bergsonism, but a sliding toward the future, without necessarily becoming Futurist. Hence, in Oxilia's film, the cinema is defined as a form of youthful temporality. We see here the rise of a model hostile to the aestheticizing imperative of the Italian cultural tradition, which is one steeped in archeology and the past. Space, aging, history are the diva's enemies - the components of a stale, theatrical kind of cinema she wishes to leave behind. By contrast, temporality and cloth, rather than architecture and the female body, pave the way for the mysterious "fourth dimension," so difficult to represent outside the conventions of calendars and clocks, and so precious and profoundly subjective an experience that, on the very eve of World War I, science and magic, positivism and spiritualism fought over its redefinition and appropriation.

Georgia Institute of Technology

\section{NOTES}

1. See Papini 1951. Also on Papini and Bergson, see Mazzei 2002.

2. All my information on Nino Oxilia comes from Martinelli 1991.

3. See Martinelli 1994.

4. See Comuzio 1987.

5. Retroscena was reprinted as Marvana: Mistero d'Amore (Carli 1927).

6. In the Feltrinelli volume of Boccioni's papers, an asterisk follows the word attrice (actress), and at the bottom of the page, the editor suggests Lyda Borelli.

7. For my juxtaposition between Futurism and Cubism, I was influenced by Marta Braun (1992).

8. Evidence exists that Boccioni read Bergson's Matter and Memory in the public library of Milan.

\section{BIBLIOGRAPHICAL REFERENCES}

Bergson 1998: Henri Bergson, Creative Evolution [1907], New York, Dover Publications Inc., 1998. 
Boccioni 1971: Umberto Boccioni, Gli scritti editi e inediti, Milan, Feltrinelli, 1971.

Borelli 1915: Lyda Borelli, "Antiprefazione," in Mario Carli, Retroscena: romanzo, Milan, Lombardo, 1915, pp. 7-8.

Braun 1992: Marta Braun, Picturing Time: The Work of Etienne-Jules Marey (18301904), Chicago, The University of Chicago Press, 1992.

Carli 1927: Mario Carli, Marvana: mistero d'amore [Retroscena, 1915], Milano, Casa Editrice Alpes, 1927.

Comuzio 1987: Ermanno Comuzio, "Rapsodia Satanica (1915) e la Musica di Mascagni,” Cineforum, no. 265, 1987, pp. 7-12.

Delpeut 1999: Peter Delpeut, Diva Dolorosa: reis naar het einde van een eeuw, Amsterdam, Meulenhoff, 1999.

Fergonzi 2004: Flavio Fergonzi, "On the Title of the Painting Materia," Boccionil Materia: Futurist Masterpiece and the Avant-garde in Milan and in Paris, New York, Solomon R. Guggenheim Museum, 2004.

Gariazzo 1919: Piero Antonio Gariazzo, Il teatro muto, Turin, Lattes, 1919.

Gunning 2003: Tom Gunning, "Loie Fuller and the Origins of Cinema," in Richard Allen and Malcolm Turvey (eds.), Camera Obscura/Camera Lucida: Essays in Honor of Annette Michelson, Amsterdam, Amsterdam University Press, 2003.

Martinelli 1991: Vittorio Martinelli, "Nino Oxilia," in Riccardo Redi (ed.), Cinema italiano muto (1905-1916), Rome, CNC Edizioni, 1991, pp. 71-86.

Martinelli 1994: Vittorio Martinelli, Il dolce sorriso di Maria Iacobini, Roma, Associazione per le Ricerche di Storia del Cinema, 1994.

Mazzei 2002: Luca Mazzei, "Quando il cinema incontró la filosofia: il caso di Giovanni Papini," Bianco e Nero, nos. 3-4, 2002, pp. 68-87.

Papini 1922: Giovanni Papini, "Enrico Bergson," Twenty-four Brains, New York, Thomas Y. Crowell Co., 1922.

Papini 1951: Giovanni Papini, "La Filosofia del cinematografo" [1907], in Maria Adriana Prolo, Storia del cinema muto italiano, Milan, Poligono, 1951, pp. 27-29. 